\title{
Carta ao Leitor
}

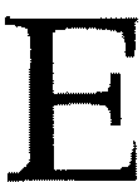

sta edição introduz mais uma modificaçăo na $\mathrm{RAE}$, cuja necessidade se fazia sentir há tempo, mas que somente agora pôde ser viabilizada: a partir de agora, todos os artigos passam a apresentar um resumo e palavras-chave em portuguès e em ingless. Com isto, o leitor terá a comodidade de poder ter uma idéia do que é tratado em cada texto antes de lê-lo integralmente e aquilatar de modo imediato o interesse que the desperta. Mas, o mais importante é que se facilita o trabalho de classificaçăo das matérias pelas bibliotecas e catálogos nacionais e internacionais, agilizando-se as tarefas de pesquisa, bem como a difusão e a circulaçăo das idélas e informaçōes contidas nos textos da RAE, o que certamente redundará em be neficios para o público e para os autores.

Com relação ao conteúdo desta edição, a matéria de capa não é um texto de "administração de empresas" no sentido estrito. Mas o tema que ela aborda - a dívida externa - embora já esteja até ficando "antigo", continua a ser uma das grandes dores

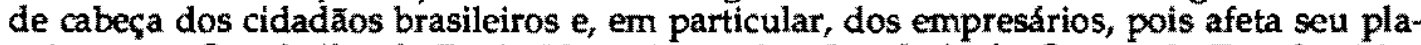
nejamento. $O$ trabalho de Paulo Nogueira Batista Jr., chefe do Centro de Estudos Monetários e de Economia Internacional da F.G.V., discute o que pode ser feito com relação à nossa dívida externa, sem resvalar para o campo das soluç̋̃es mágicas, mas também sem se deixar intimidar pelo medo paralisante das "retaliaçốes a que estaríamos sujeitos" no caso de tomarmos unilateralmente determinadas decisðes. E um texto que merece leitura atenta dos empresários, discussão e, eventualmente, mobilização para a ação prática.

Em outra linha de análise, Tom Dwyer busca, através dos recursos da Sociologia, variáveis-chave para o desvendamento do processo de produção dos acidentes de trabalho, um problema cuja seriedade, tanto do ponto de vista humano como administrativo, está a dispensar maiores comentários.

O artigo de Talita Ribeiro da Luz sobre o impacto da microeletrônica na profissăo de contador é um prato cheio para os profissionais dessa área, mas interessa também aos de outros setores, na medida em que explica os mecanismos pelos quais uma profissảo se torna mais ou menos vulnerável à degradaçăo pela automação, e discute as condiçoes em que isto tem maior probabilidade de ocorrencia.

Aqueles que trabalham com gestão orçamentária contam com a contribuição de Norberto Hoppen e Lúcia G. Esperança, que fazem uma avaliação dos chamados GSAD e propðem caminhos para aperfeiçoá-los.

Francisco $C$. Gomes apresenta a abordagem de Box-Jenkins no estudo dos modelos auto-regressivos/médias móveis, compara-a com outras e mostra como pode ser utilizada na análise do IBOVESPA. O importante é que esta técnica pode ser também empregada na medição e previsão de outras séries históricas relevantes para o administrador.

O interesse do texto de Helena Maria T. Crivellari e Marlene Catarina $O$. Melo, por sua vez, reside, a nosso ver, no fato de que ao discutirem a quéståo da qualificação profissional do produtor direto, mostram uma série de limitações que algumas políticas, que visam a manter maior controle sobre os trabalhadores e a reduzir custos com mäode-obra, podem infligir à competitividade das empresas que as adotam, especialmente quando elas eståo voltadas para o mercado externo. Ou seja, trazem mais informaçöes sobre onde o barato sai caro.

A pesquisa bibliográfica - sobre cultura organizacional - as resenhas e o informativo sobre livros e teses também integram este número. Merecem, certamente, uma vista d'olhos.

Bom proveito :

Gisela T. Goldenstein

Redatora-Chefe da RAE 